Overview of Nordic media research on immigration and ethnic relations : from text analysis to the study of production, use and reception

Horsti, Karina

2008

Horsti , K 2008 , ' Overview of Nordic media research on immigration and ethnic relations :

from text analysis to the study of production, use and reception ', NORDICOM Review , vol. 29 , no. 2 , pp. $275-293$.

http://hdl.handle.net/10138/23998

acceptedVersion

Downloaded from Helda, University of Helsinki institutional repository.

This is an electronic reprint of the original article.

This reprint may differ from the original in pagination and typographic detail.

Please cite the original version. 


\title{
Overview of Nordic Media Research on Immigration and Ethnic Relations
}

\author{
From Text Analysis to the Study of Production, \\ Use and Reception
}

\author{
Karina Horsti
}

\begin{abstract}
Nordic media and communication research had reacted to the ethnically/racially and culturally changing societies since the 1980s, and the multidisciplinary field of migration, ethnic relations and the media has been shaped. This overview draws upon existing body of research, particularly on recent literature since the early 2000s, and aims to sketch out the rough lines of Nordic media research by mapping and comparing developments in this area. In addition, it points out some major outcomes and, finally, suggests future developments. The longest line of research is based on text analysis, mostly quantitative and qualitative content analysis and discourse analysis of majority media's texts on immigration and ethnic minorities. Later on, the research focus has widened to cover various dimensions of media output as well as production and reception. Although the field is intensively developing, comparative research among the Nordic countries, and between other European countries, is scarce.
\end{abstract}

Keywords: Nordic countries, migration, multicultural society, ethnic relations, media research

\section{Introduction}

Immigration to the Nordic countries from elsewhere in Europe and the world is by no means uniform. Finland, Sweden, Norway and Denmark have received immigrants in unequal numbers, in different time periods and from different countries. Therefore, the immigrant communities and ethnic groups vary a great deal in their establishment, size and composition of countries of origin. This is one of the reasons why media performance related to migration and the multicultural society varies as well. In addition, there are differences in media use among the minorities. Therefore, the overview begins with a mapping of general migration trends to the Nordic countries between the 1990s and 2006.

Nordic media and communication researchers have reacted to the changing demographic and cultural societies in all countries, and the multidisciplinary field of migration, ethnic relations and the media has been shaped more in earnest since the early 1990s. There have been initiatives to bring Nordic media research on migration and ethnic relations together in Nordic conferences and seminar exchanges. In recent years, the research community has become more connected and an institutional basis is currently 
being developed through a Nordic research network for media, migration and society and the Nordic IMER association ${ }^{1}$. However, researchers seem to tend more towards British and American research traditions than towards their Nordic colleagues with regard to referencing and inspiration. This overview looks back to the early 2000s and aims to sketch out the rough lines of Nordic media research by mapping and comparing developments in this area. In addition, it points out some major outcomes and, finally, suggests future developments.

To make this overview, I sent an enquiry to Nordic researchers who have published or worked in the area of ethnic relations, migration and the media. The outcome of the enquiry illustrates well the need for mapping and collaboration. In addition to publications, I asked their opinion on the level of Nordic research in the area and their future perspectives to develop the field ${ }^{2}$. Thirteen researchers replied. Surprisingly, many felt that the last question was too difficult and were not able to say anything about Nordic research. Well, I have to admit that preparation of this overview opened my own eyes to the Nordic media research dealing with migration and ethnic relations. There were numerous studies I did not know about and that I did not find using the typical search engines. However, as did all the Nordic researchers I was in touch with, I acknowledged the need for collaboration. This overview is intended to contribute to this development: It aims at giving an overview of the main research paths taken in the Nordic countries (excluding Iceland) and the main research findings. By doing this, I hope to find connecting points, promote inspiration and ideas for collaborative research designs, and point out some of the main black holes in this rather young research field.

\section{Recent Migration Trends in the Nordic Countries}

The number of immigrants has grown in all Nordic countries particularly since the early 1990s, although there has been a recent dip in the numbers of asylum seekers. Increased control of asylum policies in the European Union has decreased numbers of asylum seekers (see Figure 1). Sweden has the largest foreign-born population in the Nordic countries, Norway and Denmark have the second largest populations, and Finland has the smallest (see Figure 2).

Figure 1. Numbers of Asylum Seekers in the Nordic Countries in Years 2002-2006

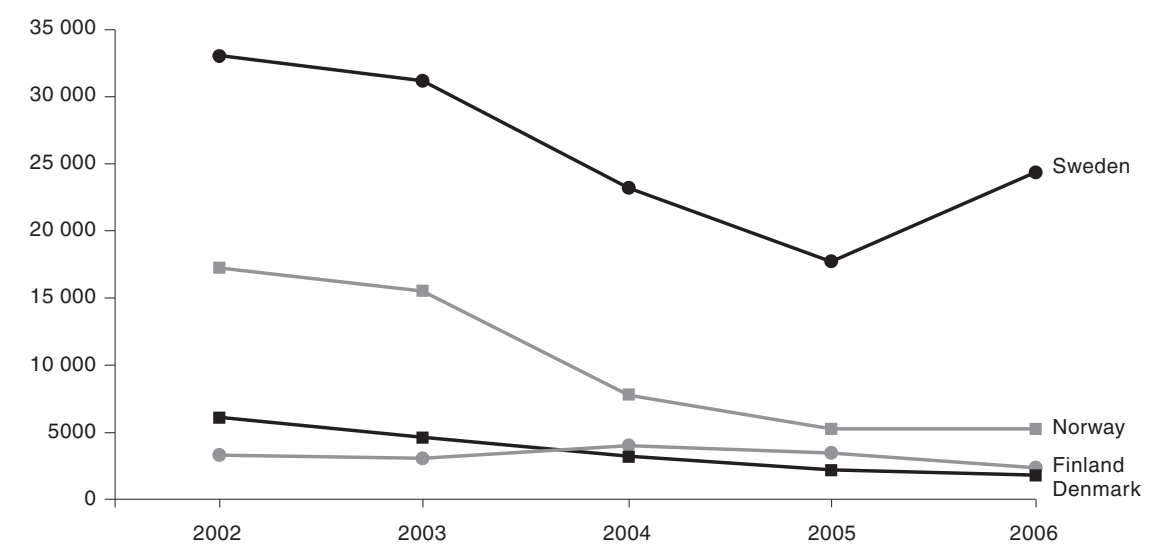

Source: http://www.migrationsverket.se/ 
Figure 2. Per Cent Age of the Foreign Born Population in the Nordic Countries 1990$2002^{3}$

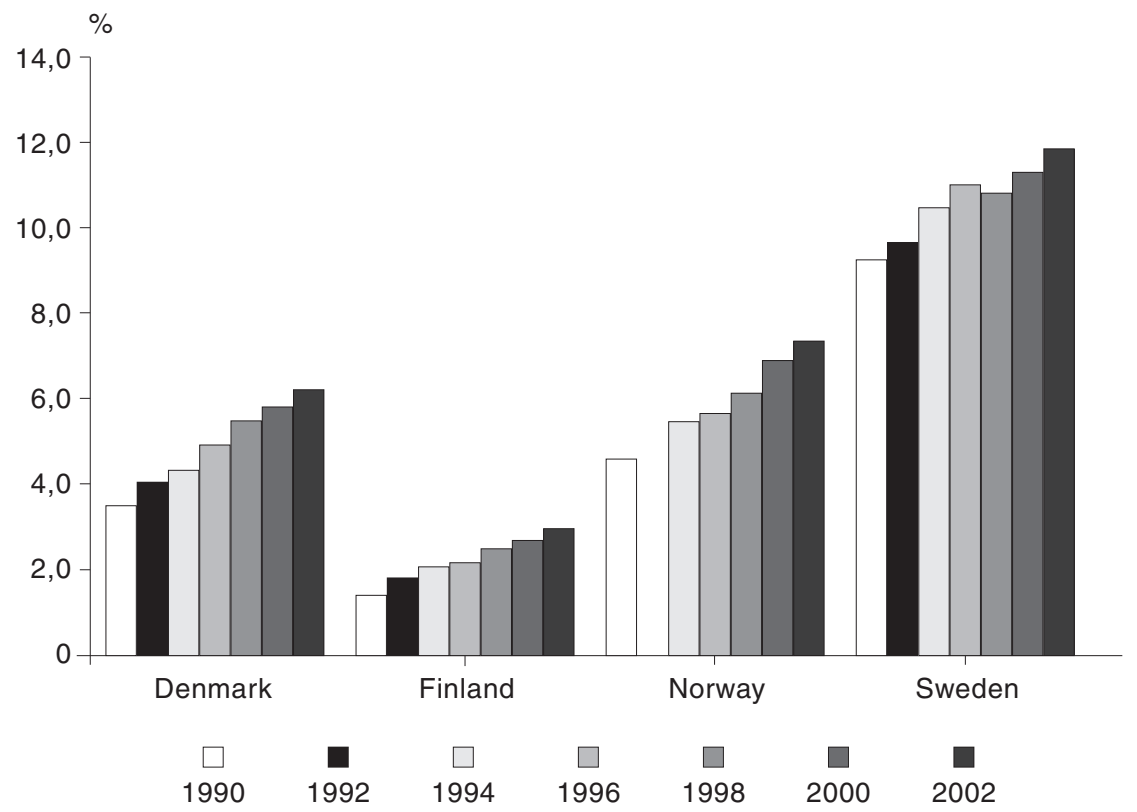

The composition of foreign-born nationals varies from country to country. The impact of neighbouring countries is significant in Finland and Norway. In Denmark, the largest immigrant groups are from Turkey and Iraq, and in Sweden after the Finns come countries in the Balkans and Iran and Iraq. In Finland, the largest groups of immigrants come from the neighbouring Estonia, Russia and Sweden. Norway attracts immigrants especially from Sweden and Denmark, but significantly more also from other West European countries (See Table 1). Approximately half of Norway's immigrants come from other Nordic countries. Therefore, Denmark has more non-Nordic immigrants in relation to the total population.

Table 1. Largest Groups of Immigrants in the Nordic Countries ${ }^{4}$

\begin{tabular}{cccc} 
Finland & Sweden & Denmark & Norway \\
\hline Russia & Denmark & Turkey & Sweden \\
Estonia & Poland & Iraq & Denmark \\
Sweden & Iraq & Germany & Poland \\
Somalia & Finland & Bosnia \& Herzegovina & Germany \\
Serbia & Norway & Norway & Iraq \\
China & Serbia\&Montenegro & Great Britain & Great Britain \\
\hline
\end{tabular}

When the Eurobarometer public opinion study of 1997 surveyed the degree of expressed racism in Europe, the figures from Denmark were higher than in other Scandinavian countries. This survey measured the self-perception and self-expression of the degree of racism, and therefore it portrays the acceptance of racist attitudes in society rather than actual racist actions. However, other opinion surveys (e.g., Eurobarometer and European Social Survey) show that the Finns are sometimes closer to the Danes and even 
more reluctant towards immigrants and multiculturalism. In a European perspective, the Nordic countries are generally on the positive end of the continuum as regards acceptance of immigration and multiculturalism. Norway is not included in these European Union opinion polls. (For a summary of the surveys, see Majorities' Attitudes towards Migrants and Minorities. Key Findings from the Eurobarometer and the European Social Survey 2005.)

\section{Scope of the Overview}

Mapping research of such a multidisciplinary area is a difficult exercise, and therefore this overview should not be read as covering all research. For practical reasons, some exclusion needs to be made. First, the studies referenced here are mainly publications that focus on mass media and (new) immigration. There are a number of relevant studies that touch upon media as one of several foci, but these are not included in the present overview. Second, in this diverse field, one needs to look for previous research in many disciplines intersecting with various disciplines such as political studies, gender studies, anthropology, sociology, social psychology, demography, geography, cultural studies, journalism and mass communication studies, media studies, film studies and so on. In the present overview, I have concentrated on research conducted in journalism and mass communication studies and media studies. Third, the field is diverse in terms of methodological and paradigmatic research paths. However, I have aimed to cover most of these main paths.

In any even, knowing the limitations one has in mapping this diverse research domain, I still find it relevant to take a more general view on the research paradigms and paths that have been taken in different countries. This article will therefore give a macro level mapping of research: general designs, methodologies, questions and findings in the area of media, immigration and ethnic relations. By doing this, I hope to make this crossroads of various disciplines more accessible for students and researchers and to help them articulate the role of mediated communication in demographically and culturally changing societies. Mass media and communication are crucial in all phases of immigration. Mass mediated images of Scandinavia and transnational communication among migrants and ethnic minorities contribute to the mobility of people. Mass mediated framings of immigrants and minorities influence the attitudes in host societies as well as integration and immigration policies. In addition, the media play a role in integration, identity and belonging.

The overview focuses mainly on research published in the period 2000-2007, as the first doctoral-level research projects were published in the early 2000s in all countries. Dissertations are important to the development of the field, because they provide overviews of previous research and analyse the state of the art in depth as well as contribute to the development of theory and concepts, which does not take place to the same extent in other research reports and journal articles. Previous research is mapped out in a European overview coordinated and published by the EUMC (ter Wal 2002) ${ }^{5}$. In addition, there are three published overviews in national languages: 1) an overview focusing partly on the Swedish mass media research presented in Paul Lappalainen's (2005, 127-169) report on power and structural discrimination, 2) Thomas Tufte's (2001, 5-16) overview of Danish media research on ethnic minorities and 3) Karina Horsti's (2000, 79-88) overview of Finnish research ${ }^{6}$. The publications have been collected from various databases (Nordicom, EBSCOhost Electronic Journals Service, SAGE Communication Journals, 
DOAJ Directory of Open Access Journals). In addition, together with Leonor Camauër I conducted a questionnaire survey among Nordic researchers working on ethnic relations, migration and the media in December 2006 - March $2007^{7}$.

Research on ethnicity, migration and the media is highly multidisciplinary in nature, which makes mapping the field complicated. Both migration research and media research are multidisciplinary. Therefore, researchers working at the crossroads are affiliated not only with departments of communication and media studies, but also other disciplines in the social sciences and humanities. Therefore, it is quite impossible to treat this area of research in terms of traditional academic divisions into disciplines and departments. Instead, we should consider this domain as a multidisciplinary research area that has emerged out of various networks and theoretical and methodological perspectives, which overlap at various points. This creates both challenges and numerous possibilities for researchers working in the field. The concepts are not always understood similarly, and theoretical and methodological backgrounds vary. There are different trends in migration research, and the interest in tackling these issues has increased significantly in many social and humanistic sciences since the 1980s.

\section{General Characteristics of the Multidisciplinary Research Field}

Scandinavian countries have organized well their multidisciplinary research field of ethnic and migration studies ${ }^{8}$ by forming national associations (IMER Sweden and Norway, ETMU Finland) with regular conferences. In addition, a Nordic association will be initiated at the $14^{\text {th }}$ Nordic Migration Researcher Conference in November 2007. However, these joint enterprises have been more focused on demography, political science, sociology and anthropology. Media and communication sciences have just recently joined these activities. Moreover, there is an increasing interest in creating research environments around the multidisciplinary field of ethnic and migration studies: CEREN at the University of Helsinki, Finland, CULCOM at the University of Oslo, Norway, IMER at the University of Bergen, Norway, CEIFO at Stockholm University, Sweden and AMID at the University of Copenhagen, Denmark.

There has been a range of Nordic collaboration between communication researchers at the Nordic Media and Communication Conferences (Kristiansand Norway 2003, Aalborg Denmark 2005, Helsinki Finland 2007), where working groups titled "Ethnic minorities and the Media"/"The media in multiethnic societies" gathered Nordic researchers active in the field. A Nordic research network was launched at a seminar organized at Södertörn University College in 2004, "Seminar of the Nordic Research Network on Media, Migration and Society". A Nordic research funding institution NordForsk has granted the Network funding for 2007-2010, ${ }^{9}$ which will develop collaboration significantly in the near future.

In all of the countries, the studies are mainly small-scale projects conducted by one or two researchers. Larger national projects do not exist, except in Sweden, where the Ministry of Justice has published a number of research reports including media studies in their research programmes on integration, structural discrimination and power relations ${ }^{10}$. Media research was part of this effort. Furthermore, there is a conspicuous lack of comparative research between Nordic countries as well as between European and Nordic countries.

Scientific development in terms of qualifications began around the same time in all Nordic countries. The first doctoral dissertations on the subject of migration, ethnic 
relations and the media were published in the early $2000 \mathrm{~s}^{11}$. However, Birgitta Löwander defended the first doctoral dissertation in the area in 1997 in Uppsala, Sweden; the work dealt with racist and anti-racist public debate. The research focused on neo-Nazis events in Sweden in 1991-1992 and public debates on these events. Löwander claims that the Swedish news media pathologize racism, presenting it as a problem of some individuals, not as a problem of society at large. The study has remained the only larger project specifically dealing with the representation of outspokenly racist groups, on the one hand, and with anti-racist campaigning, on the other.

Media research on the representation of ethnicity and immigration can be roughly divided into research on ethnic minority media and on majority media. In Finland and Norway, there is a lack of research focusing on minority media, which is most likely a result of the number and composition of migrant communities. There is significantly less ethnic media produced in these countries than in Denmark and Sweden. It is not only the number of people with an immigrant background that counts, but also the countries of origin. Both Sweden and Denmark have proportionately higher numbers of non-Western European migrant communities, which creates more need to produce minority media. In any event, the research on ethnic minority media and transnational and diasporic media has increased in all Nordic countries, a trend also seen in other European countries and the United States. As Leonor Camauër $(2003,69)$ points out, both majority and minority media are vital components of ethnic minorities' communication environment ${ }^{12}$.

Media have been analysed from three main perspectives: 1) media production, 2) text (including visual images), and 3) reception and use. This division does not mean that there are not studies combining these perspectives. For instance, Elisabeth Eide (2002; 2003) combines analysis of journalistic professional practise, text analysis and interpretation of the interviewees with an immigrant background. In the following section, I will give an overview of research conducted in Sweden, Finland, Norway and Denmark on mainstream media, and I will organize the sections according to the three perspectives, beginning with text analysis and then moving first to production and second to use and reception.

\section{Where it all Began: Quantitative and Qualitative Text Analysis}

Analysis of media texts forms the largest body of research in all countries ${ }^{13}$. This is the viewpoint from which examination of the field began. The roots generally lead to a research tradition that began in the 1970s and that analysed representations of gender in media texts. The research on mainstream media can be divided into analysis of mainstream journalism (especially the news and current affairs), multicultural initiatives and entertainment. Research on these three areas exists in all Nordic countries.

There is a large variety of text analysis in Sweden, and clearly this line of research is most developed there. For instance, there is analysis from a historical perspective comparing coverage in different periods (e.g., Brune 2004; Hulten 2006), from the gender perspective (e.g., Brune 2003; 2004) as well as analysis of various genres such as film (e.g., Wright 1998; Tigervall 2005), multiculturally oriented journalism (e.g., Christiansen 2001), news in national press (e.g., Brune 2004; 2006), news in local press (Hultén 2006a,b; Johansson 2006), current affairs programmes and talk shows (Ghersetti 2001; Camauër 2007), sports journalism (Eriksson 2006), educational television programmes (Runcis 2001) and mainstream media's treatment of minority media (Graf 2007). 
The first publications on immigration and media were published in the 1980s from the perspective of mainstream news coverage of immigrants (Hedman 1985; Hultén B. et al 1988; Brune 1990). Content analysis of various time periods (Hedman 1985; Asp 1998; Hultén G. 2006a) reveal that coverage of immigration and ethnic relations has increased significantly over the years from the 1960 s to the present. For instance, the news coverage was three times more intensive in 2000 than in 1965 (Hultén G. 2006a). The reporting has varied thematically over the years, but since the 1990s, the multiplicity of framings and sources has increased. However, new immigration, criminality, cultural affairs and sports have maintained their general popularity as news topics throughout the years from 1965 to 2000 (Hultén G. 2006a).

Similar trends have been seen in other Nordic countries, however, with a shorter time period. For instance, in Finland, Sari Pietikäinen $(2000,151)$ demonstrates that the coverage of ethnic minorities and immigrants quadrupled from the mid-1980s to the early 1990's in the main Finnish newspaper Helsingin Sanomat. Moreover, new immigration and problem-oriented news themes are accentuated in the general coverage in Denmark and Finland as well. However, it is impossible to compare the coverage, as all countries use different categories in their coding sheets. For instance, a news media monitoring project in Finland illustrates that the main topics in the news between the years 1999-2004 have been 1) the relations between Finnish society/citizens and migrant groups; 2) law and administrative actions; 3 ) infringement of judiciary (without violence); 4) court proceedings and 5) arrival of new immigrants (Raittila and Vehmas $2005,15)$. This may suggest that the Finnish coverage is slightly more framed in terms of administrative control than it is in Sweden. Furthermore, the lack of ethnic minorities' appearance in the sports section in Finland compared to the other Nordic countries is a significant difference. Of the Nordic countries, Finland still has the smallest proportion of immigrants for the least number of years, and news trends may reflect this early stage of development of a multicultural society. The media are still more focused on administrative issues, whereas the issues of the ethnic minorities themselves have not come into focus. However, the monitoring research indicates that some changes are occurring in Finnish society. A significant increase has occurred in the coverage of court proceedings, but also in the themes of unemployment and job application, which could indicate an increase in framing minority issues more in terms of integration.

In Norway, Elisabeth Eide $(2002 ; 2003)$ discusses changes in the journalistic perspective between the 1980s' stress on the exotic and culture and the 1990s' focus on problems and negative issues of immigration. Eide's research material focuses on problems, notwithstanding the existence of "multiculturally" oriented feature stories.

In Denmark, the research field began to develop from a text analysis perspective in the mid-1980s (Tufte 2001, 9), but in further studies various other perspectives have been taken as well. There is research on representations of Muslims and Islam (Hussain 2000; 2002; 2003; Hervik 2002), on the gender perspective (Andreassen 2005), historical perspective (Jensen B. 2000) and on multicultural documentaries (Marselis 2003). The Prophet Mohammed caricature case generated a number of research projects in Denmark (Larsen \& Seidenfaden 2006; Hervik 2007). The Muslim issue has been controversial in Denmark even before the cartoon case. Muslims have been presented as the main deviant group in the news media, and they were positioned as the opposite of ethnic Danes and Danishness already in the 1990s. Moreover, the Danish media tend to frame Islam in the context of fundamentalism and extremism, which increases the images of threat (Hervik et al. 1999; Hussain 2000; Hervik 2002). The routine news 
coverage in Denmark is mainly negatively biased: The main topics in 1996 in the news broadcasted in public television and radio were first of all crime and violence and second immigration and asylum seeking (Hussain et al. 1997, 52). More recent research reveals that problem framing and nationalistic orientation dominate the news coverage (Madsen 2000; Andreassen 2005).

In Finland, the coverage of Russians and Estonians has received some particular attention in the research (Raittila 2004; Jerman 2004; Haavisto 2005), which is important given that these groups are the most negatively represented in the Finnish media. In addition to the focus on Russians and Estonians, Raittila (2004) has developed a methodology for analysing agency and dialogic communication within single news stories.

In Norway, media coverage of immigrants was first discussed at the end of 1990s in a more journalistic publication (Fjedstad and Lindstad 1997, 1999). Among Norway's immigrants, Europeans form the largest group and they are presented more positively than are immigrants with origins outside Europe.

News coverage of immigrants and ethnic minorities was the first area researched in Sweden as early as in the 1980s and early 1990s, particularly by one of the pioneers, Ylva Brune. Ylva Brune and Gunilla Hultén used both quantitative and qualitative content analysis methods. Moreover, both compared journalistic output over time. Similar research designs combining quantitative data and more intensive analysis with qualitative methods have been applied also in Finland (Pietikäinen 2000; Raittila 2004, 2002; Haavisto 2004, 2007) and in Denmark (Hussain et al. 1997). These studies reveal that it has been crucial, especially in the early stage, to map the coverage using quantitative methods and to obtain more detailed knowledge of the subtle mechanisms of discrimination using qualitative methods.

Ylva Brune (2004; 2006) and Gunilla Hulten (2006a and b) looked not only at the representation of immigrants, but also at the representation of Sweden and Swedishness. Journalism tends to frame Swedishness as a goal every immigrant should, first, strive for and, second, adapt to. Sweden is presented as the "drömlandet" (literally, "dream country"), as Brune characterizes it. The identifications of the majority have also been the object of analysis in other countries. When the media produces images of minorities, they also produce images of the majority. However, it is quite interesting how the representations of the majority are not equal across the Nordic countries, but instead how they vary from one imagined national community to another. Whereas in Sweden the national imaginary highlights "folkhemmet" (literally, "the people's home"), which as qualities that will "rescue" immigrants from their "backward" lifestyles, the Norwegian image stresses the "superpower of human rights" (Eide and Simonssen 2007). In contrast, the Finnish reflection in the ethnic mirror is totally different from the two above, which contributes to a self-image of a powerful and great nation. The media in Finland repeatedly construct the fantasy of a hiding place where the Finnish people can be homogenous and safe. Finland does not carry the burden of colonialism, but is itself been "colonialized" by Russia and Sweden. The media discourse claims that because Finland is small and in the periphery, it has no obligation to help the Other (Horsti 2005, 291-292; 2007b).

Although the Swedish research has mainly focused on the mainstream news media, there are also studies on entertainment genres, such as Carina Tigervall's (2005) dissertation in which she uses discourse analysis to study ethnic and national identities produced in Swedish films in the period 1970-2000. Movies both created and challenged existing power relations between the Swedes and the Others. Immigrants were 
presented as "sympathetic others" in anti-racist discourses. However, these "positive", yet patronizing, framings and identifications did not weaken the division between the majority and the minorities. Immigrants were still presented as the opposite of Swedes. For instance, when the films wanted to criticize the materialistic (Swedish) way of life, immigrants represented a traditional way of life.

In Finland, there have been few entertainment programmes and films produced that have an ethnic minority dimension. However, a new shift was experienced in the middle of 2000 in Finnish television when a number of fiction series were introduced. These programmes catalyzed public debates, but not yet research. In Norway, Elisabeth Eide and Anne Hege Simonsen are launching a research project to analyse the "minority beat" in journalism and fiction.

In the Swedish research, the gender dimension has been influential and incorporated into many of the studies (see, e.g., Tigervall 2005; Hultén G. 2006a; Brune 2004). The Swedish academic debate has found intersectionality a crucial concept, and researchers pay attention to the interplay of ethnicity, gender and class. Gender issues have been important in Europe, especially in the British research tradition on race and ethnicity, and should be more developed in the Nordic countries. The popular image of a strong, equal and independent Scandinavian woman brings its own challenges to the media analysis, which could be worked out together among Nordic colleagues.

The "honour killing" of Fadime Sahindal in 2002 in Sweden is one key event that was debated in all Nordic countries. The gender dimension has been important both in the public debate and in academic examinations of these debates. The case has evoked research in Finland ${ }^{14}$, Norway (Simonsen 2004) and Sweden (Grip 2002; Reimers 2005; Strand Runsten 2004). In Sweden, the debate was framed largely in cultural terms: A dichotomy between Swedish culture and Kurdish/Muslim cultures was created. Simonsen (2004), in her comparison of Norwegian and Swedish tabloid newspaper coverage of the issue, argues that the case was framed according to a Romeo and Juliet mythical story: The Swedishness of Fadime's boyfriend was stressed instead of his partly Iranian background. In this way, the story could be told in terms of clashing cultures. Key events such as Fadime Sahindal's killing are the thickenings of multicultural debates in which cultural and national definitions are negotiated in the public space. Therefore, cases that are discussed in different countries simultaneously offer good crossroads for comparative research.

Research on media texts with new focuses is currently being conducted in all Nordic countries. The historical dimension is being applied in Norway in a project directed by Elisabeth Eide (Eide \& Simonsen 2007), which looks back on one hundred years of Norwegian news journalism. Media representation of Islam and people with an Arab background is a focus that has been given significant attention in Nordic media research in the past few years ${ }^{15}$. One example of this tendency is the bi-annual Nordic media research conference where, in 2007, five presentations out of 12 were related to Islam. Moreover, the Prophet Mohammed caricatures event provoked a number of studies in the Nordic countries as well as an international comparative study (Kunelius \& Eide 2007). In the comparative field there is also Reeta Pöyhtäri's (2007) ongoing doctoral research on periodicals in Finland and the Netherlands, Anne Hege Simonsen's already mentioned study on coverage of "honour killing" in Norway and Sweden, Pekka Kuusisto's (2000) doctoral dissertation on linguistic manifestations of ethnicity in British and Finnish newspapers as well as research on Finnish and Swedish newspaper coverage of the African migration "crisis" in Spain from the perspective of the European public sphere and 
mediatized ritual (Horsti 2007a). Furthermore, there is new research on genres such as the women's magazines (Marselis 2005; 2006; Pöyhtäri 2007) as well as on new media such as blogs (Mainsah 2007).

\section{Journalistic Production: Focus on Minority Journalists}

In the analysis of production, the focus has been on journalists with an immigrant background. How have they made it into the media profession in the Nordic countries? How have the newsrooms and other production companies encountered the demographically and culturally changing society? In addition, multicultural initiatives in the mainstream media, such as educational and consultative projects and special programming, have received academic attention (Christiansen 2001; Horsti 2005, 183-276; 2007b). There is a lack of research on the journalistic process and professional practices as well as on other media production in fiction and entertainment. We cannot not really know how the tenacious frames are being produced by only focusing on the output. There are negotiations and debates going on inside the editorial rooms that are not explicit in the news story. How is selection and salience negotiated? Are the debates merely issues of political correctness or are there more profound debates in the newsrooms? Furthermore, transnational media enterprises and circulation of formats, ideas and readymade stories may be increasingly contributing to the changes in the representation of ethnic minorities.

Studies on journalistic production are rather scarce in all Nordic countries, although in Sweden there are studies on journalists with an immigrant background, focusing on career development and multicultural editorial rooms (Djerf-Pierre \& Levin 2005; Camauër 2006). In addition, a mapping project was conducted among the main media and schools of journalism in Denmark, Norway and Sweden by Elin Svensen (2000) to get an overall picture of the involvement of journalists with an immigrant background in the media field. In Denmark, Iben Jensen (2000) has analysed in more detail the career development of journalists with an immigrant background. Recently, research projects have been initiated that will apply similar perspectives ${ }^{16}$.

There have been numerous multicultural initiatives to foster the careers of journalists with an immigrant background and to increase studies in journalism among young people with migrant families in all Nordic countries. There are no studies concentrating on these initiatives, although research on career development often touches upon the role of multicultural projects. Leonor Camauër (2006) argues that journalists with a minority background in Sweden experience a great gap between rhetoric (policy) and practice. A similar division is presented by Christian Christiansen (2001) in his analysis of the Swedish public broadcaster's multicultural policies and actual programming.

Based on the research mentioned above, the challenges and possibilities of increasing diversity in journalistic production in the Nordic mediascape can be divided into three groups: structural issues, cultural competences and cultural-structural mechanisms. Structural diversity refers to various educational, professional and institutional discriminatory mechanisms that marginalize minorities as well as "positive discriminatory" mechanisms aimed at promoting diversity in the journalistic profession. The main obstacles to improving diversity are, first, the class-specific nature of the journalistic profession in Sweden, second, weak networks with the social elite among the socio-economically less advantaged minorities (an obstacle also for the young people from less advantaged Swedish families), and third, migrants' low level of mastery of the Swedish language and 
- more importantly - the assumption of poor language skills. Quotas have not become popular in any Nordic newsroom or university offering journalistic education, although in 2006 Oslo University College introduced a quota system for five students per year with ethnic minority background, based on a recommendation from the Ministry of Education ${ }^{17}$. However, multiculturally oriented projects that aim to increase minorities among both journalism students and journalists in the mainstream media are run in all Nordic countries, and there seems to be great confidence among journalists, minorities and educators that these projects offer the best solution to the lack of diversity.

There are obstacles and opportunities related to cultural competences. Swedish research stresses that employers appreciate diverse cultural capital in their editorial rooms. It is interesting how certain events have exposed the need for diversity within newsrooms. For instance, the disco fire in Göteborg, where a number of especially ethnic minority youth died, revealed to the mainstream media that their editorial rooms did not have contacts with the people affected by the tragedy. Still, journalists with an immigrant background are often regarded as having a poorer understanding of the Swedish culture and society than native Swedes do. These attitudes among employers seem to be changing slowly, as similar arguments are used in Finland (which as a more recent immigration) (Suihkonen 2003). Moreover, families with an immigrant history tend to value more traditional professions such as business, medicine and law (Jensen 2000). Thus, a journalistic profession is not as appreciated among these families as among native Swedish families. Some explanations for this bias are that young people perceive the journalistic profession negatively (dangerous, involving censorship) due to their greater transnational perspective and experience. Moreover, lower wages, discrimination and racism associated with media representation of ethnic minorities reduce the attractiveness of a journalistic profession. These types of issues have not been analysed in other Nordic countries, which makes comparison impossible.

Cultural-structural mechanisms of both decreasing and increasing minority participation in the journalistic profession reflect the combination of cultural specifics and structural features. Minority media are one such important opportunity for both journalists with an immigrant history and young people from immigrant families, but brought up in Nordic countries, to find their way to the profession. Other studies in Finland (Suihkonen 2003) and Norway (Svensen 2000) discuss the same insights as the Swedish research (Djerf -Pierre \& Levin 2005): On the one hand, minority media both offer a space to practise journalism on one's own terms and offer easier entrance into the field; on the other hand, the step to mainstream media remains wide and the ideas and views presented in the minority media still do not spread to the wider society. Moreover, minority media and mainstream media's multicultural initiatives are strongly dependent on shifting policies and orientations as well as volunteer work (Camauër 2003, 84).

Iben Jensen (2000) presents three strategies to increase the participation of people with an immigrant background in the journalistic profession. First, the media field and universities should make the profession seem more attractive among the young. Second, people with other academic qualifications should be encouraged to enter the field. Third, mainstream national media should recruit journalists working in the local media (where it is easier to enter). Leonor Camauër $(2006,21)$ concludes that increasing awareness of discrimination in the newsrooms and the need for diversity together with multicultural media policy and critical public debate can be seen as a sign of changing journalistic values and routines. 
More research is clearly needed in the field of production, as the field is still under development, not only in the Nordic countries, but also in other European countries. Nordic countries could develop research designs and propose research questions and conduct comparative pilot projects in this domain to develop analysis of journalistic production from the viewpoint of multicultural societies. Analysis should be conducted both in mainstream media and in minority media and extended to a variety of genres and media. First, the process of framing news stories on immigrant- and ethnic-relationsrelated events remains under-analysed: How do certain themes, frames and narratives persist in the news coverage? How are new ways of reporting discovered and how are practices changed? Second, the diversity and multiculturality of media companies and newsrooms need more research. What are the dynamics of multicultural working environments? How do diverse cultural competence and transnational networks influence journalistic processes?

\section{Global Public Space: Immigrants' Transnational Media Use}

The media use of immigrants and people with a migrant background is still a rather undiscovered research area in the Nordic countries, even though the area is now being examined by prominent senior researchers and in major projects. Analysis of reception has focused almost solely on the media use of minorities. Reception, effects and interpretation of majority audiences are still rather neglected ${ }^{18}$. A number of research initiatives have been taken in the field of media use of minorities:

In Finland two interrelated projects have been launched in 2007. Kaarina Nikunen (2007) focuses on the media use of young people with an immigrant background and Heikki Luostarinen, of the University of Tampere, is directing a three-year project that will, first, map the media use of immigrants in general and, second, examine the reception of immigration-related news among both native Finns and some immigrant groups.

The media practices of immigrants were studied in Sweden for the first time in the late 1990s in a survey based on interviews with 470 people (Weibull \& Wadbring 1998). However, more detailed analysis is currently being conducted. Ingegerd Rydin and Ulrika Sjöberg, of the University of Halmstad, are conducting a project entitled "Media practices in the new country". This project analyses the media use and practices of families with an immigrant history using ethnographic methods, the focus being on young people between 12 and 16 years of age.

In Norway, at the University of Oslo, Henry Mainsah has worked on CameroonianNorwegian audiences and is conducting doctoral research on migrants' use of the Internet. Sharam Alghasi, of the University of Oslo, has analysed the media practices of Iranian-Norwegians ${ }^{19}$ and is continuing this work in his doctoral dissertation. Eva Bakøy, of the University College of Lillehammer, is conducting research on television use among migrant women.

In Denmark, research on minorities' media practices began relatively early. In 1999, Connie Caroe Christiansen (2003) analysed media use among the largest immigrant groups originating from outside Western Europe. Thomas Tufte $(2000 ; 2002 ; 2003)$ studied the media use of young people in one area in Copenhagen and analysed media use more generally in collaboration with Maja Riis (Tufte \& Riis 2001). In addition, Peter Hervik (1999) analysed reception among majority audiences in 1997. The research design included both textual analysis of Ekstrabladet's and Jyllands-Posten's journalistic 
content and audiences' reception of the same newspapers. Hervik concludes that the xenophobic attitudes among audiences were mainly based on the negative representation of immigrants repeatedly produced in these newspapers.

Concepts of identity, transnational and diaspora are widely used and currently explored in Nordic research on media use among minorities. Research results suggest that people with a migrant background live increasingly in a global and transnational public sphere. They gather information from a variety of sources, while stressing the media in countries of origin and international media. Nevertheless, what media people follow depends greatly on their country of origin. For instance, African television channels are not available in the Nordic countries. National Nordic media are often experienced as presenting immigrants negatively and increasing hostility in the surrounding society (Christiansen \& Sell 2000; Alghasi 2007; Mainsah 2005). Mustafa Hussain (2002; 2003) suggests that this is one of the main reasons why people with an immigrant background in Denmark prefer to get their information from international sources.

In the public debates, the media use of immigrants is often approached as an integration issue, the starting point being the general assumption that transnational media use decreases integration and loyalty to the new country. This nationalistic, however, view has been disproved in the research, for instance in studies by Christiansen (2003; 2004) and Tufte (2003), who claim that in a transnational situation it is natural and facilitative of integration to follow media in a diverse manner. Actually, participation in the public debates and interest in social issues in the new country are related to social capital and self-esteem. Therefore, migrants who are active participants in transnational communities are often active participants in the host society. Christiansen $(2004,188)$ suggests that watching television news from the homeland should be characterized as a transnational practice. Migrants are generally gathering information and entertainment through more multiple channels than are the native-borns, and therefore they live in a much more transnational space. However, depending on the language skills, it is not only the news from countries of origin that migrants tend to follow, but also international media such as Al Jazeera or BBC World are among the channels that are often watched. The reasons for not choosing to watch Danish language channels are experienced racism within the news texts and lack of sufficient language skills (Christiansen 2004, 193). Moreover, Tufte (2003) highlights that the media use of the young is diverse. American talk shows, series and movies unite the young no matter which background they have. Still, young people are very much aware of the "ethnic" conflicts that receive intensive media attention. Their experience supports the claim that news coverage constructs a division between "us" and "them".

\section{For Future Research: New Perspectives, Comparative Research and Collaboration}

To sum up, the development of the field in the Nordic countries started in the 1980-1990s and was based on text analysis, mostly quantitative and qualitative content analysis and discourse analysis of majority media's texts on immigration and ethnic minorities. The first research initiatives asked what topics were raised by the mainstream media, what viewpoints and sources were stressed. Later on, the research focus has widened to cover various dimensions of media output as well as production and reception. Nordic researchers are currently taking these steps as research initiatives are being pursued from new perspectives. Still comparative research among the Nordic countries, and 
between other European countries, is scarce. This is surprising, especially considering that there is no language barrier to comparison, as Nordic people can understand each other's languages, except that the Finnish language media cannot be understood by other Scandinavians. One reason for the lack of comparison may be that many studies are financed by national institutions and associations aiming to produce knowledge for national policy making ${ }^{20}$. Furthermore, the policy orientation influences the quality of research: A substantial part of the research tends to be descriptive mapping and reporting rather than theoretically and methodologically innovative research. In addition, there is a lack of international publications, although some of the studies, e.g. doctoral dissertations, are of high quality. There is only one Nordic publication within this theme (Tufte 2003), albeit excluding Finland.

There is clearly a need to develop collaboration among researchers studying ethnic relations, migration and the media at various levels - national, regional, European and global - to solve some of the problems in the field. Due to the relative youth of the field in many countries and its multidisciplinary nature, the networks of individual doctoral students and senior scholars as well as institutions should be wider. Not all institutions have expertise in the field, which makes international mentoring schemes, seminars and summer schools crucial for young researchers. Furthermore, media and communication sciences should increase its presence within international research associations dealing with migration and ethnic relations.

\section{Notes}

1. At the time of writing, a multidisciplinary Nordic IMER association is being established, the chair located at SAXO Institute, University of Copenhagen. More information about the Nordic Research Network for Media, Migration and Society please visit http://sockom.helsinki.fi/ceren/migranord/

2. This last question was as follows: How would you characterize Nordic research on ethnicity, immigration and the media? What should be strengthened methodologically, theoretically and/or empirically?

3. Migration Policy Institute, MPI Data Hub. www.migrationinformation.org. [Referred 16.5.2007].

4. Finnish data on "foreign-born nationals" from 2006 published by the Ministry of Interior, Työministeriön maahanmuuttotilastoja www.mol.fi (referred 9.5.2007), Swedish data on "immigration" from 2005, (Statistics Sweden, SCB, gives a list of countries of origin of immigrants by year, which makes comparison difficult. Therefore, this list characterizes the immigrants who arrived during 2005 (excluding Swedish nationals). Danish data from 2006 Statbank Denmark www.statbank.dk (referred 9.5.2007), Norwegian data from 2006 Statistisk sentralbyrå www.ssb.no (referred 9.5.2007).

5. Overview of research in the EU15 countries illuminates the state of research between 1995-2000, including Finland, Sweden and Denmark (ter Wal 2002).

6. See also an earlier overview by Pietikäinen and Luostarinen (1997).

7. I would like to thank all the researchers who replied to the questions. Special thanks to Leonor Camauër who has initiated the Nordic collaboration in the first place at Nordic conferences of communication researchers and within the Nordic research network. I am also thankful to Eija Poteri, Nordicom Finland, who performed the data search.

8. In the Nordic countries, this research field is characterized mainly using the terms ethnicity, ethnic minorities, immigration, migration and integration. Terms such as race and race relations are not generally used, although the role of socially constructed "race" is recognized in research on discrimination and racism.

9. Nordic Research Network for Media, Migration and Society. For further information: http://sockom. helsinki.fi/ceren/migranord/index.html or contact project leader Karina Horsti at http://sockom.helsinki. fi/ceren/english

10. These reports are available electronically at SOU (Statens Offentliga Utredningar) documents. http:// www.sweden.gov.se/sb/d/108; jsessionid=aeh7odptLbie [Referred 28 August 2007].

11. In Finland, doctoral dissertations in the field so far are Männistö 1999 (media images of Islam); Pietikäinen 2000; Kuusisto 2000; Raittila 2004; Horsti 2005; Nordberg 2007 (partly media related). In Sweden, Löwander 1997; Brune 2004; Nygren 2004; Roosvall 2004 (partly related to ethnic minorities), Dahlsted 
2005; Tigervall 2005; Hultén 2006. In addition, Merja Ellefson and Anna Levin are defending their dissertations in 2007. In Denmark: Marselis 2003 and Andreassen 2005. Prior to these dissertations, books by Mustafa Hussain, Ferruh Yilmaz \& Tim O’Connor (1997) and Peter Hervik (2002) were central to the development of the field in Denmark. In Norway, only one doctoral dissertation has been published to date on the topic under analysis here; it is by Elisabeth Eide (2002). However, Eiri Elvestad at NTNU in Trondheim will soon defend a dissertation on media use of Norwegian-Vietnamese.

12. Minority media in Finland (Kauranen \& Tuori), Sweden (Camauër) and Denmark (Hussain) have been mapped in a project coordinated by Myria Georgiou. Reports available at http://www.lse.ac.uk/collections/EMTEL/Minorities/reports.html [Referred 28 August 2007]. For a mapping of Swedish minority media see also Camauër 2005.

13. By the term 'text' I mean all genres of media texts and images in print media, television, radio, and the new media.

14. Suvi Keskinen at the University of Tampere, Finland, is currently analysing media coverage of the case as one part of her post-doctoral research on ethnicity and violence directed at women.

15. In addition to international research on the Prophet Mohammed caricatures (Kunelius \& Eide 2007), there is research in all countries on Islam and Muslims in the media. Danish research in this area was referred to earlier. In Finland, Mari Maasilta, Pentti Raittila (both University of Tampere) and Karin Creutz (University of Helsinki) are currently conducting a study focusing on mainstream media's presentation of Islam and Muslims.

16. A joint research project on multicultural newsrooms in Berlin and Stockholm was initiated in 2007 by Heike Graf and Gunilla Hultén of Södertörn University College. (Mångfaldslinjer: Journalistisk produktion ur ett mångkulturellt perspektiv i Stockholm och Berlin). Gunn Bjørnsen, Hogskolen i Oslo, is working on a doctoral dissertation on cultural competence in editorial rooms and journalist education.

17. The journalist programme at the university had a committee that also discussed several strategies to increase the number of ethnic minority students. To qualify for the programme, the student and/or both parents have to be born outside of Norway. Source: Interview with lecturer Anne Fogt 18 August 2007.

18. There has been pilot focus group research on the reception of majority youth and adults in Finland (Nikunen 2007; Raittila 2007).

19. http://www.culcom.uio.no/forskning/artikler/mainsah-eng.html [Referred 23. July 2007.]

20. Some examples: In Sweden, the first study in the field was published by the Labour Market Department (Arbetsmarknadsdepartmentet) (Hedman 1985) as part of a report on discrimination. In addition to universities and colleges, other institutions financing and ordering research in the Nordic countries have been the national journalist's associations, various state departments and ministries.

\section{Bibliography}

Andreassen, Rikke (2005) Mass Media's Construction of Gender, Sexuality, Race and Nationality. An Analysis of the Danish News Media's Communication about Visible Minorities. Toronto: University of Toronto.

Asp, Kent (1998) 'Flyktingrapporteringen i Rapport', JMG Granskaren 2/98. Göteborg: Göteborgs universitet.

Bakøy, Eva (2007) Migrant Women and Television. Presentation at the NordMedia Conference, Helsinki 15-19 August 2007.

Brune, Ylva (1990) Flyktingfrågorna i pressen 1985-1988. Stockholm: Delegationen för invandrarforskning.

Brune, Ylva (2003) 'Den mystistka kulturkrocken. "Invandrarkillen" och "invandrartjejen" i mediehändelsernas mitt', in T. Tufte (ed.) Medierne, minoriteterne og det multikulturelle samfund. Skandinaviske perspektiver. Göteborg: Nordicom, pp. 49-76,

Brune, Ylva (2004) Nyheter från gränsen. Tre studier i journalistik om "invandrare”, flyktingar och rasistisk våld. Göteborg: JMG.

Brune, Ylva (2006) 'Den dagliga dosen. Diskriminering i nyheterna och bladet', in Leonor Camauër \& S.A. Nohrstedt (eds.) Mediernas vi och dom. Mediernas betydelse för den strukturella diskrimineringen. Stockholm: Statens Offentliga Utredningar, pp. 89-122. http://www.regeringen.se/sb/d/6155/a/58634 (Referred 28 August 2007).

Camauër, Leonor (2001) 'Sweden', in Myria Georgiou (ed.) National Context - Transnational Perspectives - Mapping Commonalities and Differences in Diasporic, Ethnic Experience and the Media in Europe, http://www.lse.ac.uk/collections/EMTEL/Minorities/reports.html (Referred 28 Aug. 2007).

Camauër, Leonor (2003) 'Ethnic Minorities and their Media in Sweden. An Overview of the Media Landscape and State Minority Media Policy', Nordicom Review 2/2003. http://www.nordicom.gu.se/common/publ_ pdf/32_069-088.pdf(Referred 23. July, 2007)

Camauër, Leonor (2005) Minoritetsmedier i Sverige - en kartläggning. Stockholm: Styrelsen för Psykologiskt Försvar, http://www.psycdef.se/global/PDF/Publikationer/minoritetsmedier.pdf 
Camauër, Leonor (2006) 'Mediearbetare med utländsk bakgrund och majoritetsmediers diskrimineringsmekanismer', in Leonor Camauër \& S.A. Nohrstedt (eds.) Mediernas vi och dom. Mediernas betydelse för den strukturella diskrimineringen. Stockholm: Statens Offentliga Utredningar, pp. 35-88, http://www. regeringen.se/sb/d/6155/a/58634 (Referred 28 August 2007).

Camauër, Leonor (2007) 'Så många "kulturskillnader" - så få nyanser...', in Ekström, Mats och Kroon, Åsa (eds.) Paketerad politik - Elva essäer om journalistik och medier, Stockholm: Carlssons bokförlag, pp. 112-132.

Christiansen, Christian (2001) 'Minorities, Multiculturalism and Theories of Public Service', in Ullamaija Kivikuru (ed.) Contesting the Frontiers. Media and Dimensions of Identity. Göteborg: Nordicom.

Christiansen, Connie Caroe \& Lea Sell (2000) Godt stof eller medborger? Nyheder og etniske minoriteter I Danmark. Copenhagen: Socialforskningsinstituttet.

Christiansen, Connie Caroe (2003) 'Tv-nyheder fra hjemlandet - integration eller ghettoisering? Om transnationalisme og nyhedsforbrug', in T. Tufte (ed.) 'Medierne, minoriteterne og det multikulturelle samfund', Skandinaviske perspektiver. Göteborg: Nordicom, pp. 157-180.

Christiansen, Connie Caroe (2004) 'News Media Consumption among Immigrants in Europe. The Relevance of Diaspora', Ethnicities 4(2): 185-207.

Creutz, Karin (2007) Islam in the Swedish-language Press in Finland. Presentation at the NordMedia conference, Helsinki 15-19 August 2007.

Dahlstedt, Magnus (2005) Reserverad demokrati. Representation i ett mångetniskt Sverige. Umeå: Boréa.

Djerf-Pierre, Monika \& Levin, Anna (2005) 'Mediefältets janusansikte: medieeliten, journalisterna och mångfalden', in Makten och mångfalden. Eliter och etnicitet i Sverige. Rapport från Integrationspolitiska maktutredningens forskningsprogram, pp 165-224. Stockholm: Justitiedepartementet, Regeringskansliet. http://www.sweden.gov.se/sb/d/5071/a/47490;jsessionid=aeh7odptLbie (viitattu18.5.2007).

Eide, Elisabeth (2002) "Down there" and "up here". Europe's Others in Norwegian Feature Stories. Oslo: Faculty of Arts.

Eide, Elisabeth (2003) 'The Long Distance Runner and Discourse on Europe's Others. Ethnic Minority Representation in Feature Stories', in T. Tufte (ed.) Medierne, minoriteterne og det multikulturelle samfund. Skandinaviske perspektiver. Göteborg: Nordicom, pp. 77-114.

Eide, Elisabeth \& Simonssen, Anne (2007) Falling Angels. The End of the Colourful Community? Presentation at the NordMedia conference, Helsinki 15-19 August 2007.

Eriksson, Göran (2006) 'Om sportjournalistikens inkluderande mekanismer', in Leonor Camauër \& S.A. Nohrstedt (eds.) Mediernas vi och dom. Mediernas betydelse för den strukturella diskrimineringen. Stockholm: Statens Offentliga Utredningar, pp. 225-256. http://www.regeringen.se/sb/d/6155/a/58634 (Referred 28 August 2007).

Ghersetti, Marina (2001) Personer med invandrarbakgrund i Rapport, Aktuellt, Sportnytt, Kulturnyheterna. Göteborg: Göteborgs universitet.

Graf, Heike (2007) How Mainstream Media Observe Minority Media. Presentation at the NordMedia conference, Helsinki 15-19 August 2007.

Grip, Lena (2002) Mediernas syn på De Andra. En medieanalytisk studie i samband med mordet på Fadime. Karlstads universitet: Institutionen för samhällsvetenskap, Avdelningen för Geografi och Turism.

Haavisto, Camilla (2004) Etniska minoriteter och etnicitetsfrågor i Hufvudstadsbladet och Vasabladet. Mediemonitoreringens resultat från perioderna September-Oktober 1999, 2001 och 2002. Rapporter och diskussionsinlägg 4/2004. Helsinki: CEREN, University of Helsinki.

Haavisto, Camilla (2005) Ryssar och estländare i finlandssvensk press: de berövar oss, tjänar oss och behöver vår hjälp, Nordicom Information 27(4): 55-66.

Haavisto, Camilla (2007) 'Med sikte på en inkluderande och likvärdig medierapportering - Etnisk, kulturell och religiös mångfald i finlandssvensk dagstidningsjournalistik 1999-2005', in Camilla Haavisto \& U1lamaija Kivikuru (eds.) Variera mera, inkludera flera. Atta essäer om medier, mångfald och migration, 83-120. SSKH Meddelanden 71. Helsinki: University of Helsinki.

Hedman, Love (1985) 'En explorativ studie av invandrarbilden i massmedia', in Hedman et al. (eds.) Invandrare $i$ tystnadsspiralen. Journalisten som verklighetens dramaturg. Stockholm: Arbetsmarknadsdepartementet.

Hervik, Peter (1999) Den generende forskellighed. Danske svar på stigende multikulturalisme. Copenhagen: Hans Reitzels Forlag.

Hervik, Peter (2002) Mediernes muslimer. En antropologisk undersøgelse af mediernes dcekning af religioner $i$ Damark. Copenhagen: The Board for Ethnic Equality.

Hervik, Peter (2007) 'Denmark: A Political Struggle in Danish Journalism', in Kunelius et al. (eds) Reading the Mohammed Cartoons Controversy. Working papers in international journalism 2007/1. Bochum: Projektverlag.

Horsti, Karina (2000) 'Media ohittaa "toisen": Suomen mediatutkimus etnisyydestä, rasismista ja maahanmuutosta', Tiedotustutkimus 23(4): 79-87. 
Horsti, Karina (2005) Vierauden rajat monikulttuurisuus ja turvapaikanhakijat journalismissa. Tampere: Tampereen yliopisto.

Horsti, Karina (2007a.) 'Hopp och vanmakt: Nyheter om Afrika, Europa och om dem som färdas där emellan', in Camilla Haavisto \& Ullamaija Kivikuru (eds.) Variera mera, inkludera flera. Atta essäer om medier, mångfald och migration. Helsinki: University of Helsinki, SSKH Meddelanden 71, 31-50.

Horsti, Karina (2007b.) 'Managed Multiculturalism in Finnish Media Initiatives', International Journal of Multicultural Societies 9(1). http://portal.unesco.org/shs/en/ev.php-URL_ID=2547\&URL_DO=DO TOPIC\&URL SECTION=201.html.

Hultén, Britt (1988) 'Att skriva om flyktingar', in Hultén et al (eds.) Journalister, invandrare flyktingar. Stockholm: Journalisthögskolan.

Hultén, Gunilla (2006a.) Främmande sidor: Främlingskap och nationell gemenskap i fyra svenska dagstidningar efter 1945. Stockholm: University of Stockholm, JMK. http://urn.kb.se/resolve?urn=urn:nbn:se: su:diva-1035 (Referred 1. June 2007.)

Hultén, Gunilla (2006b.) 'Främlingar i nationens spegel', in Leonor Camauër \& S.A. Nohrstedt (eds.) Mediernas vi och dom. Mediernas betydelse för den strukturella diskrimineringen, pp. 123-162. Stockholm: Statens Offentliga Utredningar. http://www.regeringen.se/sb/d/6155/a/58634 (Referred 28 August 2007).

Hussain, Mustafa (2000) 'Islam, Media and Minorities in Denmark', Current Sociology 48(4), pp. 95-116.

Hussain, M., Yilmaz, F., O’Connor, T. (1997) Medierne, minoriteterne og majoriteten. En undersogelse af nyhedsmedier og den folkelige diskurs i Danmark. Copenhagen: Thorup Forlag.

Hussain, Mustafa (2001) 'Denmark', in Myria Georgiou (ed.) National Context - Transnational Perspectives - Mapping Commonalities and Differences in Diasporic, Ethnic Experience and the Media in Europe, http://www.lse.ac.uk/collections/EMTEL/Minorities/reports.html (Referred 28 Aug. 2007).

Hussain, Mustafa (2002) ,Denmark', in Jessika ter Wal (ed.) Racism and Cultural Diversity in the Mass Media. Vienna: EUMC.

Hussain Mustafa (2003) 'Media Representation of Ethnicity and the Institutional Discourse', in Thomas Tufte (ed.) Medierne, minoriteterne og det multikulturelle samfund. Skandinaviske perspektiver. Göteborg: Nordicom.

Jensen, Bent (2000) De fremmede i Dansk avisdebat. Fra 1870'erne til 1990'erne. Copenhagen: Spektrum.

Jensen, Iben (2000) Hvornår er man lige kvalificeret? Etniske minoriteters profesionelle adgang til etablerede danske medier. Copenhagen: Naevnet for etnisk ligestilling.

Jerman, Helena (2004) Russians as presented in Finnish TV documentaries, The Global Review of Ethnopolitics 3(2): 79-88.

Johansson, Marcus (2006) 'Husbondens röst i etnifierad lokalpress', in Camauër \& Nohrstedt (eds.) Mediernas vi och dom. Mediernas betydelse för den strukturella diskrimineringen. Stockholm: Statens Offentliga Utredningar, pp. 163-188, http://www.regeringen.se/sb/d/6155/a/58634 (Referred 28 August 2007).

Kauranen, Ralf \& Tuori, Salla (2001) 'Finland', in Georgiou (ed.) National Context - Transnational Perspectives - Mapping Commonalities and Differences in Diasporic, Ethnic Experience and the Media in Europe, http://www.lse.ac.uk/collections/EMTEL/Minorities/reports.html (Referred 28 Aug. 2007).

Kunelius, Risto \& Eide, Elisabeth (2007) 'The Mohammed Cartoons, Journalism, Free Speech and Globalization', in Kunelius et al. (eds.) Reading the Mohammed Cartoons Controversy: An International Analysis of Press Discourses on Free Speech and Political Spin. Working papers in international journalism 2007/1. Bochum: Bochum Projekt Verlag cop.

Kuusisto, Pekka (2000) Ethnicity in Print. Implicit Linguistic Manifestations of the Construction of Ethnicity in British and Finnish Newspapers. Helsinki: University of Helsinki.

Lappalainen, Paul (2005) Det blågula glashuset - strukturell diskriminering i Sverige. Statens Offentliga Utredningar, SOU 2005:56. Stockhom: Regeringskansliet, http:/www.regeringen.se/sb/d/5073/a/46188 (Referred 28 August 2007).

Larsen, Rune Engelbreth \& Seidenfaden, Toger (2006) Karikatur krisen. En undersøgelse af baggrund og ansvar. Copenhagen: Gyldendal.

Lindstad, Merete \& Fjeldstad, Øyvind (1997) Innvandrere, fremmedfrykt og norske medier: En undersokelse av uvalgte mediers dekning av saker knyttet til innvandrere og flyktninger, fremmedfrykt og rasisme. Oslo: Norsk Journalistlag.

Lindstad, Merete \& Fjeldstad, Øyvind (1999) Pressen og de fremmede. Kristiansand: IJ-forlaget.

Löwander, Birgitta (1997) Rasism och antirasism på dagordningen - studier av televisionens nyhetsrapportering $i$ början av 1990-talet. Umeå: Umeå University.

Maasilta, Mari \& Raittila, Pentti (2007) Islam in Finnish Media. Presentation at the NordMedia conference, Helsinki 15-19 August 2007.

Madsen, Gaarde Jacob (2000) Mediernes konstruktion af flygtninge- og indvandrersporgsmålet. Copenhagen: Magtudredningen. 
Mainsah, Henry Nsaidzeka (2005) Media Use and Changing Identities: The Case of Cameroonians in Oslo. University of Oslo, Master's Dissertation. http://wo.uio.no/as/WebObjects/theses.woa/wa/ these?WORKID=31268 (Referred 23. July 2007.)

Mainsah, Henry Nsaidzeka (2007) Multi-Ethnic Youth Online: Open Spaces of Participation. Presentation at the NordMedia conference, Helsinki 15-19 August 2007.

Marselis, Randi (2003) Foler du dig dansk? Forhandlinger af idenitetsmaessige tilho/rsforhold i dansk tv-dokumentarisme om det multietniske samfund. Copenhagen: Minoritetsstudier (Dr.Diss.).

Marselis, Randi (2005) 'Majoritetspiger som grænsemark/or: Om perkerpiger og konvertitter i mediebilledet', in H. Bech \& A.S. Sorensen (eds.) Kultur på kryds of tvaers. Århus: Klim, pp. 43-64.

Marselis, Randi (2006) Afrosurinamske skønheder, in B. Eriksson et. al. (eds.) Smagskulturer og formidlingsformer. Århus: Klim, pp. 165-189.

Männistö, Anssi (1999) Islam länsimaisessa hegemonisessa diskurssissa-Myyttis-ideologinen ja kuva-analyyttinen näkökulma sivilisaatioiden kohtaamiseen. Tampere: Tapri tutkimuksia, Rauhan- ja konfliktintutkimuskeskus.

Nannestad, Peter (2001) 'Den svære integration: Danskere og de nye etniske minoriteter', in Peter Seeberg (ed.) Ubekvemme udfordringer. Aktuelle tendenser i den danske og europaeiske indvandrerdiskussion. Odense: Odense Unversitetsforlag, pp. 13-31.

Nikunen, Kaarina (2007) Immigrant Youth and Popular Media. Presentation at the NordMedia conference, Helsinki 15-19 August 2007.

Nordberg, Camilla (2007) Boundaries of Citizenship: The Case of the Roma and the Finnish Nation-state. Turku: Åbo Akademi.

Nygren, Gunnar (2004) Skilda medievärldar. Lokal offentlighet och lokala medier i Stockholm. Stockholm: JMK.

Pietikäinen Sari (2000) Discourses of Differentiation. Ethnic Representations in Newspaper Texts. Jyväskylä: University of Jyväskylä.

Pietikäinen, Sari \& Luostarinen, Heikki (1997) 'Minorities in Finnish Publicity', Nordicom Information Nr. 4/1997, 19-31.

Pöyhtäri, Reeta (2007) Conceptualizing Social Identities of Immigrant Groups. Presentation at the NordMedia conference, Helsinki 16-19 August 2007.

Raittila, Pentti (2002) (ed.) Etnisyys ja rasismi journalismissa. Tampere: Tampere University Press.

Raittila, Pentti (2004) Venäläiset ja virolaiset suomalaisten Toisina. Tapaustutkimuksia ja anlyysimenetelmien kehittelyä. Tampere: Tampere University Press.

Raittila, Pentti \& Vehmas, Susanna (2005) 'Etnisyys ja rasismi sanomalehdissä 1999-2004 - seurantatutkimusten yhteenvetoa ja arviointia', in Pentti Raittila (ed.) Etnisyyttä, rasismia ja dialogia sanomalehdissä ja Internetissä. University of Tampere: Dept. of Journalism and Mass Communication Studies, pp. 11-32.

Reimers, Eva (2005) 'En av vår tids martyrer. Fadime Sahindal som mediehändelse', in Med Rätten i Fokus. Lund: Studentlitteratur.

Roosvall, Anna (2004) Utrikesjournalistikens antropologi. Nationalitet, ethnicitet och kön i Svenska tidningar 1987, 1995 och 2002. Stockholm: JMK (Dr.Diss.).

Runcis, Maija (2001) "Sverige är inte hela världen" : folkbildning för och om invandrare i utbildningsprogrammen. Stockholm: Stiftelsen Etermedierna i Sverige.

Simonsen, Anne Hege (2004) 'Fadime. Ett drap - to historier. Tabloide nyhetsjegere på rett spor?', in Elisabeth Eide \& Anne Hege Simonsen (eds) À se verden fra et annet sted. Medier, norskhet og femmendhet. Oslo: Cappelens Forlag.

Strand Runsten, Pia (2006) '”Hedersmord", eurocentrism och etnicitet', in Leonor Camauër \& S.A. Nohrstedt (eds.) Mediernas vi och dom. Mediernas betydelse för den strukturella diskrimineringen. Stockholm: Statens Offentliga Utredningar, pp. 189-224. http://www.regeringen.se/sb/d/6155/a/58634 (Referred 28 August 2007).

Suihkonen, Minna (2003) "Kukaan ei halua elää semmosta elämää, jossa omaa ääntä ei kuulu”. Haastattelututkimus etnisten vähemmistöjen omasta mediasta ja vähemmistötaustaisten toimittajien pääsystä valtamediaan. http://www.uta.fi/jourtutkimus/MinnaSuihkonen-lop-rap.pdf.

Svensen, Elin (2000) Multietniske redaksjoner? Rekruttering av journalister med minoritetsbakgrunn $i$ Danmark, Norge og Sverige. Fafo-rapport 342. Oslo: Fafo. http://www.fafo.no/pub/342.htm (viitattu 18.5.2007).

Tigervall, Carina (2005) Folkhemsk film med "invandraren” i rollen som den sympatiske Andre. Umeå: Umeå universitet.

Tufte, Thomas (2000) Ny teknologi: friscettelse eller fastholdelse? Unge etniske minoriteters brug af chat, internet og mobil telefoner. Sekvens 2000. Copenhagen: University of Copenhagen.

Tufte, Thomas (2001) 'Medierne og de etniske minoriteter i Danmark - traditioner i og udfordringer for dansk medieforskning', MedieKultur Nr.32: 5-16. 
Tufte, Thomas (2002) 'Ethnic Minority Danes between Diaspora and Locality - Social Uses of Mobile Phones and Internet', in Gitte Stald \& Thomas Tufte (eds) Global Encounters. Media and Cultural Transformation. Luton: University of Luton Press.

Tufte, Thomas (2003) 'Minority Youth, Media Uses and Identity Struggle. The Role of the Media in the Production of Locality', in T. Tufte (ed.) Medierne, minoriteterne og det multikulturelle samfund. Skandinaviske perspektiver. Göteborg: Nordicom. pp. 181-196,

Tufte, Thomas \& Riis, Maja (2001) 'Cultural Fields, Communication and Ethnicity. Public Libraries and Ethnic Media Supply in a Neighbourhood of Copenhagen’, Gazette 63(4): 331-350.

ter Wal, Jessika (ed) (2002) Racism and Cultural Diversity in the Mass Media. An Overview of Research and Examples of Good Practice in the EU Member States 1995-2000. Vienna: EUMC/ERCOMER.

Weibull, Lennart \& Wadbring, Ingela (1998) 'De nya svenskarna möter svenska massmedier', in L. Nilsson (ed.) Region i omvandling. Göteborg Universitet: SOM-institutet.

Wright, Rochelle (1998) 'The Visible Wall: Jews and Other Ethnic Outsiders in Swedish Film', Uppsala: Uppsala universitet. 
